\title{
1. Service business: growth, innovation, competitiveness
}

\author{
John R. Bryson and Peter W. Daniels
}

\section{INTRODUCTION}

All capitalist economies are service economies and all manufacturing-dominated economies have been simultaneously service economies (Bryson et al., 2004). It is difficult to design, manufacture and sell a product without providing service functions. There are many different types of services, from those that directly support the production of goods and other services - the producer or business and professional services - to personal services including tourism, health care and education. A walk through a supermarket highlights the role that marketing, advertising and packaging design services play in our society. Simple products incorporate quantities of visible and often invisible service expertise; the former is seen in advertising campaigns and the latter is found in logistics services that ensure that raw materials and completed manufactured goods are transported and distributed efficiently. Much of the service expertise hidden within products arises from the constant search for product differentiation.

The process of corporate and product differentiation through blending service expertise with the manufacture of products is reflected extremely effectively in the development of the concept of the unique selling proposition (USP). After the Second World War, Rosser Reeves, an American advertising executive who ran the Ted Bates Advertising Agency, used to stand before a potential client, reach into his pocket and extract some loose change. He would select two quarters and announce that his job was to persuade consumers that the quarter in his right hand was worth more than the one in his left hand (Twitchell, 2004: 5-6). This process he labelled as the creation of a USP which involved, for Reeves, developing stories and associations that were attached to goods; this contributed to the development of strong brands. Reeves's brother-in-law, David Ogilvy (1911-1999), developed the 'proposition' part of the USP through placing stories on products (Ogilvy, 1983). He was the first Scottish sales representative for Aga, the manufacturer of cast iron range cookers, and during his time there Ogilvy created the company's sales manual; a book that defined a sales process built on understanding consumer behaviour and aspirations and the development of stories.

The economies and societies of developed market economies are saturated with service jobs, activities, firms and functions. In many developed market economies there has been a continual growth in service employment and a decline in employment in manufacturing. Nevertheless, the economic downturn that commenced in 2008 has seen a renewed interest by governments in stimulating manufacturing production. Thus, between 2012 and 2013 there was growth in employment in both manufacturing and services in Chile, Hungary, Ireland, Japan, Korea, New Zealand, Poland, the 
Table 1.1 Employment in manufacturing and service, 2012 and 2013 (all persons)

\begin{tabular}{|c|c|c|c|c|}
\hline & \multicolumn{2}{|c|}{ Service Employment } & \multicolumn{2}{|c|}{ Manufacturing Employment } \\
\hline & 2012 & 2013 & 2012 & 2013 \\
\hline Australia & $8,685,688$ & $8,819,650(+)$ & 948,107 & $921,999(-)$ \\
\hline Austria & $2,884,525$ & $2,896,000(+)$ & 660,075 & $651,125(-)$ \\
\hline Canada & $13,635,730$ & $13,847,730(+)$ & $1,785,517$ & $1,734,217(-)$ \\
\hline Chile & $5,047,329$ & $5,189,401(+)$ & 881,428 & $882,185(+)$ \\
\hline Czech Republic & $2,876,650$ & $2,935,525(+)$ & $1,299,075$ & $1,285,275(-)$ \\
\hline Denmark & $2,089,800$ & $2,097,375(+)$ & 333,825 & $325,000(-)$ \\
\hline Finland & $1,817,000$ & $1,796,775(-)$ & 356,725 & $350,300(-)$ \\
\hline Germany & $28,145,600$ & $28,613,100(+)$ & $7,917,050$ & $7,839,925(-)$ \\
\hline Hungary & $2,520,425$ & $2,567,350(+)$ & 803,100 & $823,175(+)$ \\
\hline Ireland & $1,416,250$ & $1,431,950(+)$ & 208,775 & $213,125(+)$ \\
\hline Italy & $15,687,580$ & $15,496,130(-)$ & $4,207,650$ & $4,128,775(-)$ \\
\hline Japan & $44,771,670$ & $45,230,830(+)$ & $10,317,500$ & $10,390,000(+)$ \\
\hline Korea & $17,184,430$ & $17,502,510(+)$ & $4,104,900$ & $4,184,017(+)$ \\
\hline Netherlands & $6,917,800$ & $6,941,775(+)$ & 771,700 & $768,225(-)$ \\
\hline New Zealand & $1,624,250$ & $1,667,150(+)$ & 245,875 & $247,675(+)$ \\
\hline Norway & $2,005,625$ & $2,017,400(+)$ & 239,125 & $228,775(-)$ \\
\hline Poland & $8,890,500$ & $8,949,050(+)$ & $2,905,800$ & $2,968,675(+)$ \\
\hline Slovak,Republic & $1,379,500$ & $1,417,825(+)$ & 570,325 & $539,475(-)$ \\
\hline Slovenia & 562,100 & $549,550(-)$ & 206,475 & $203,200(-)$ \\
\hline Spain & $13,244,230$ & $13,017,480(-)$ & $2,223,900$ & $2,118,675(-)$ \\
\hline Sweden & $3,651,500$ & $3,712,900(+)$ & 537,925 & $524,900(-)$ \\
\hline Switzerland & $3,360,250$ & $3,402,425(+)$ & 576,275 & $581,325(+)$ \\
\hline United Kingdom & $23,511,900$ & $23,917,420(+)$ & $2,886,775$ & $2,913,900(+)$ \\
\hline United States & $115,675,200$ & $116,593,800(+)$ & $14,686,420$ & $14,869,080(+)$ \\
\hline
\end{tabular}

Source: OECD, 2014.

UK and the US (Table 1.1). This highlights the complexity of economic restructuring. Thus, the replacement of manufacturing employment with service jobs has been occurring, but this is not a simple process. Manufacturing remains an important activity in most developed market economies, but most people are employed in some form of service work. In an analysis of the new economy of American jobs, Moretti noted that:

If you take a walk in one of America's cities, most of the people you see on the streets will be store clerks and hairstylists, lawyers and waiters, not innovators. About a third of Americans work either for government or in the education or health services sectors, which include teachers, doctors and nurses. Another quarter are in retail, leisure, and hospitality, which includes people working in stores, restaurants, movie theatres, and hotels. An additional 14 percent are employed in professional and business services, which includes employees of law, architecture and management firms. In total, two-thirds of American jobs are in the local services sector, and that number has been quietly growing for the past fifty years. (2013: 12) 
For Moretti, the growth of service work is the effect and not the cause of economic development. This argument is based on productivity differentials between manufacturing and services. These tend not to alter dramatically for the delivery of local services; it takes the same time to teach a child to play the piano or for a hairdresser to cut hair as it did 40 years ago. Nevertheless, there have been major improvements in productivity in manufacturing firms; every year they improve their productivity through process and product innovations and often this involves replacing people with machines.

Technological developments provide new opportunities for the creation and delivery of new services. This includes all types of Apps for smart phones and many types of Webenabled service delivery model. The development of new forms of e-commerce continues to transform high streets and shopping centres. It is interesting to note that the rise and decline of the high street shop has actually occurred over a relatively short space of time; they only only emerged as we know them in the late 17 th century. Prior to this time goods were purchased from temporary stalls set up in market places or from 'shops' without glass windows. Instead, they were protected outside working hours by window-shutters that were let down and when open supported on posts for the display of goods (Gray, 1921: 110). The word 'shop' only emerged as a verb with the meaning of going to purchase goods in the mid-18th century (1764); prior to this the term meant to expose goods for sale or a workshop (Oxford English Dictionary, 1991).

The replacement of high street shops with out-of-town shopping centres or malls and the emergence of e-commerce reflect ongoing innovations in retail services. The latest trend has been the transformation of the high street and shopping centre from a place to shop for goods into a place of entertainment and experiences. A good example is the Bluewater Shopping Centre, Kent, UK. A 30 per cent stake in Bluewater was recently sold by Australia's Lend Lease to Land Securities (White, 2013: B5). Other publicly listed property developers competed with Land Securities to purchase this stake, requiring it to pay $£ 656$ million for its share, which provides the company with an overall net initial yield of 4.1 per cent. Bluewater attracts over 27 million visitors a year and the acquisition of the 30 per cent stake in the development is part of Land Securities's strategy to focus on developing a retail investment portfolio based on dominance, experience and convenience. Retail habits are changing; visits to shopping centres are less frequent but for a longer period of time and over greater distances. The retail mix within large shopping centres is changing; ten years ago food and drink outlets would account for 5 per cent of outlets but today developers aim for at least 20 per cent. Land Securities wants to increase Bluewater's leisure outlets to at least 24 per cent. This highlights the on-going transformation of shopping centres into leisure spaces that are saturated with service experiences.

For many years services were ignored by academics, they devoted most of their energy towards understanding manufacturing firms and even agricultural activities. The relatively recent discovery of services is surprising given their pivotal contribution to the first industrial revolution. Sociologists (Wright Mills, 1953; Urry, 1987, 1990; Lash and Urry, 1994) and geographers were amongst the first social scientists to discover service employment and activities. The early attention to services by geographers (Daniels, 1982, 1985) had its roots in a 1970s research agenda that focussed on understanding the growth and location of offices (Daniels, 1979; Goddard, 1986). It was soon recognised that this topic would be enriched by looking more closely at the business activities that were major 


\section{Handbook of service business}

users of office space, the rapidly growing business and professional services (Beyers and Alvine, 1985; Beyers and Lindahl, 1996; Bryson, 1996, 1997a, b; Bryson et al., 1993a, b, 1994, 1997, 2004).

In this chapter we provide some conceptual tools for understanding the world of service business. This includes a definition of services, service histories, services and the division of labour, services and productivity, and services and manufacturing. This reflects the broad objective for this Handbook, which is to provide a systematic account of service businesses. This can be sub-divided into two sub-objectives: first, to identify a series of building blocks that can be used to understand the operations and activities of service businesses, and, second, to provide a collection of chapters that can be used to support an advanced undergraduate or graduate teaching module that is focussed on service business.

\section{DEFINING SERVICES}

In 1986, Riddle argued that the 'service sector is one of the least understood portions of our global economy', even though 'no economy can survive without a service sector' (Riddle, 1986: 6). During the 1970s and early 1980s, very few academics were interested in exploring services. Economics was still heavily influenced by classical political economists, such as Adam Smith and David Ricardo, who drew a distinction between productive and unproductive labour. According to Smith (1997: 429-430), 'there is one sort of labour which adds to the value of the subject upon which it is bestowed: there is another which has no such effect. The former, as it produced a value, may be called productive; the latter, unproductive labour.' He used this simple bipolar division of labour to argue that a whole range of service activities was essentially unproductive. The traditional meaning of the term 'service' heavily influenced Smith's understanding of services.

The word 'service' is very problematic as it has too many meanings and associations (Fellowes, 1954: 719). It comes from the Latin servitium or 'slavery'. The meaning of the term has altered so that the act of serving, for example, is no longer associated with slavery. There are many types of 'service', and these include the occupation of a servant, a public or civil servant, or religious associations based on church service, public worship or 'Divine Service' (Fellowes, 1954: 719) and serving God. The various meanings of the term are all based on the concept of the 'act of serving' and on a relationship between master (sic) and servant. As a noun a 'service' is the action or process of servicing and as a verb it describes the performance of routine maintenance or repair work or the provision of a service. The use of the word 'service' as a verb is a very recent development. In this context, Gowers noted that the verb 'service' 'is a useful newcomer in an age when almost everyone keeps a machine of some sorts that needs periodical attention' (Gowers, 1982: 46). It is also worth noting that in 1925 the term 'service' was first applied to describe 'expert advice or assistance given to customers after sale by manufacturers or vendors' (Oxford English Dictionary, 1991: 1950).

At best, then, the word 'service' is a confusing term. The association between service, servants and unproductive labour partly explains the absence of a significant body of research on services prior to the 1980s. This is not to argue that no academic work on services was undertaken. A number of important monographs made major contributions 
to understanding service work as well as beginning to trace some of the dimensions of the emerging service economy. Some of these early studies avoided the term 'service', preferring to focus on exploring white-collar work (Wright Mills, 1953) or professional people (Lewis and Maude, 1952). One of the most important of the early studies is Greenfield's research on producer services (1966). This was followed by Bell's classic account of postindustrial society (1973) that influenced Gershuny's analysis of the new service economy (Gershuny, 1978; Gershuny and Miles, 1983) and the geographical analyses by Daniels (1982, 1985) and Illeris (1996).

Scholars have found it extremely difficult to construct a rigorous definition of 'services'. Originally, the category of 'services' was a 'residual' that embraced everything that was not included in the primary (extractive) or secondary (manufacturing) sectors of the economy. This has encouraged attempts to define and identify services on the basis of their primary characteristics, two of which are supposed to delimit them from other forms of economic activity. First, the output of a service is ephemeral or non-material (for example, a lecture or theatrical performance) and, second, the production and consumption of a service occur simultaneously. There are obvious difficulties with both of these characteristics; some services are not ephemeral and do have materiality (software, or even a haircut) and some can be stored (software, servicing of a machine).

All attempts to classify services also recognise the complexity and diversity of the business activities that need to be included. A simple classificatory schema of service activities identifies five different types:

1. Consumer services that provide services for final end-users.

2. Producer and business services that provide intermediate inputs into the activities of private- and public-sector organisations.

3. Public services provided directly by the state or indirectly by the private sector and not-for-profit organisations.

4. Not-for-profit organisations working beyond the confines of the state.

5. Informal services or unpaid service work, which is usually predominantly undertaken by women, and which is a vital element of people's daily lives.

Each type describes a heterogeneous collection of service functions. They comprise several distinctive sectors (law, accountancy, market research, technical consultancy, etc.) as well as a very broad size-range of firms. Producer services in particular make an important contribution to economic development as they contribute directly to the creation of added value; they contribute to a national economy's balance of payments through exports and have also given rise to dramatic growth rates both in employment and in new firm formation.

It is usually assumed that producer service firms perform an important role in knowledge creation, as well as in shaping regional competitiveness. However, it is easier to assert this relationship than it is to successfully test its existence because it is difficult and perhaps impossible to develop objective measures of the impacts of producer service firms on client companies or regional competitiveness. 


\section{SERVICE HISTORIES}

It is worth noting at the outset the common mistake of assuming that transformation of economies towards services is a phenomenon of the 20th century. The social sciences have paid too little attention to the role services played during the industrial revolution and earlier. The considerable rise in the importance of services in the latter half of the 18 th century has been largely ignored. A case example is the United Kingdom. Using fire office registers to undertake an investigation into the structure of London's economy between the years 1775 and 1825, Barnett, for example, provides an unusually detailed historical investigation from which it is concluded that:

service industries made no less contribution to the British economy during the Industrial Revolution than manufacturing, and that nowhere was this more true than in London. Its service economy was on a very large scale, serving the nation as a whole as well as the capital ... London's service industries underpinned both its own and the national manufacturing and commercial infrastructure and at the same time contributed to the new 'commercialisation of leisure'. (Barnett, 1998: 183)

During the late 19th century London was already being transformed into a key world city, a process that has continued up to the present to ensure its status as a global city. Deane and Cole $(1962$ : 166, 175) calculated that in 1851 some 45.3 per cent of the UK's national income was derived from service activities (trade, transport, housing, the professions, civil service, etc.). The structure of employment changed dramatically during the 19th century as a result of technological innovation and the increasing maturity and extension of the capitalist system. Employment growth occurred in occupations that facilitated the exchange of goods and services between producers and consumers. Between 1881 and 1901 the number of business clerks increased from 175,000 to 308,000 , bank officials from 16,000 to 30,000 and insurance officials and clerks from 15,000 to 55,000 (Marsh, 1977: 124). During the 19th century international trade was continuously impeded by financial problems until it was enabled and supported by the establishment of bill markets and banking facilities of the kind associated with the flow of tea and silk from China to Europe between 1860 and 1890 (Hyde, 1973). As the UK was becoming an industrialised society it was simultaneously being transformed into a service economy; the growth of manufacturing employment went hand in hand with the growth of service employment. This was an on-going transformation and it is evident in many different indicators of social and economic transformation.

The development of a market economy based around agricultural products and manufactured goods required the development of supporting services. During the 18th century market towns developed to 'service and supply a thinly populated countryside, but also to gather the products of rural industries such as handloom weaving, glove making and stocking knitting for onward transmission to the regional and national markets' (Pinches, 2009: 44). Nevertheless, all market-based transactions, however primitive, required supporting services including logistics and accounting.

Circulation, trade and exchange are essential pre-conditions for the emergence of capitalism. These activities are closely related to service functions. The development of international trade is associated with the creation of a supporting international financial 
system. During the 18th century London developed as a centre of a 'wide intricate, multilateral network of world trade ... with its wide sheltered anchorages, its vast wharves and warehouses, its rich banks, its specialists in marine insurance and its world-wide mercantile contacts ... It drew to itself a cosmopolitan concentration of wealth and expertise' (Deane, 1969: 56).

Business and professional service (BPS) functions emerged as market-based activities became ever more complex. The history of capitalism is one in which important qualitative changes in the management and organisation of business emerge. These new processes and BPS functions gradually became commonplace. Thus, at the beginning of the 17 th century a stock market was opened in Amsterdam; 'Government stocks and the prestigious shares of the Dutch East India Company had become objects of speculation in a totally modern fashion' (Braudel, 1988: 101). This was not the first stock market as State loan stock had been negotiable in Florence before 1328. The difference between the Florence and the Amsterdam stock markets was in the volume of transactions, fluidity and publicity (Braudel, 1988: 101). Thus, the difference between Amsterdam's first stock market and that of the London stock market in 2014 is one of scale and complexity. To Braudel, during the 17 th century:

speculation on the Amsterdam Stock Exchange had reached a degree of sophistication and abstraction which made it for many years a very special trading-centre of Europe, a place where people were not content simply to buy and sell shares, speculating on their possible rise or fall, but where one could by means of various ingenious combinations speculate without having any money or shares at all. (Braudel, 1988: 101)

The Amsterdam stock market was intertwined with the development of trade and a series of related supporting and facilitating services.

\section{THE DIVISION OF LABOUR}

The division of labour is central to the history of capitalism; new tasks, functions or activities emerge that reflect specialisation within labour markets. The onset of mass production with the development of the assembly lines in the early years of the last century is associated with the emergence of mass consumption. This requires the development of sophisticated forms of marketing, advertising, branding and packaging and this led to the emergence of another set of supporting service functions. It is impossible to separate service functions from manufacturing as each supports the other. Technological developments in the design and manufacture of office technology (the telephone, photocopiers, typewriter, telex machines, fax machines, computers, e-mail) enabled major innovations to occur in office-based services. Similarly, innovations in services, from advertising to logistics, played a critical role in the emergence of mass production systems.

The outsourcing of service functions and the creation of new types of service occupations may represent an increase or extension of the division of labour. An increasing division of labour reflects both increasing specialisation of activity with a resultant increase in the complexity of production, and alterations in the way in which production is organised. Here the important point is the extended labour process (Sayer and Walker, 


\section{Handbook of service business}

1992; Walker, 1985), which is work that occurs before and after goods and services are physically produced. Thus, research and development, design, market research, trial production, product testing, marketing, customer care and sales are all essential parts of the production process. The fact that they can be separated in both time and space from the actual production process does not necessarily imply that they are not an integral part of the manufacturing sector of the economy. Ultimately, this means that the dramatic growth in business service employment reflects alterations in the way in which manufacturing production is organised, rather than the development of a service or knowledge economy.

\section{SERVICES AND PRODUCTIVITY}

In his economic theory of services, Baumol (1967, see also Baumol et al., 1989) distinguishes 'progressive' services (those oriented towards the application of technology in production and which can therefore achieve improved rates of output per capita) from 'non-progressive' services (substitution of technology for labour is not possible). In relation to the latter, the nature of the production process determines that the work done (such as a ballet or an opera, a consultancy) cannot be speeded up or abbreviated in the interests of improved productivity (by reducing the number of dancers or performers, devoting less time to researching and preparing a consultancy report). This would be unacceptable to those watching or listening to the performance or those paying to obtain the best advice from a consultant. There is therefore very little scope for productivity improvements of the kind possible in the 'progressive' services, where innovation, economies of scale or developments in information and communication technologies (ICTs), for example, can be adopted to achieve increases in productivity. The overall implication is that over time services become more costly relative to goods. If it is assumed that the demand for services is inelastic to price, but that demand will continue to increase as living standards rise, there will be a steady transfer of employment from the progressive to the non-progressive parts of the economy. The result is not only a general shift of employment from manufacturing to services but also a shift from the progressive to the non-progressive sectors within services.

The Baumol model has the attraction of simplicity but it does assume that measures of output and productivity used for progressive activities are readily transferable to non-progressive activities. Recent advances in ICTs indicate that many service activities are much more open to the substitution of new technology and economies of scale for production, thus diminishing the credibility of the 'productivity gap' thesis that is central to Baumol's case. But at least Baumol and fellow economists such as Fuchs $(1965,1969)$ recognised the new and expanding role for services in the economy. Meanwhile, others such as Galbraith (1967) effectively ignored services in their analyses of the growth and diversification of industrial economies and societies, even though in Europe and in the US some 40-50 per cent of the labour force was employed in service industries by the end of the 1950s. 


\section{MANUFACTURING AND SERVICES - HYBRID PRODUCTION PROCESSES AND HYBRID PRODUCTS}

Manufacturing has changed but our understanding of it has not. The production process of both goods and services has become blurred; service firms increasingly provide service functions that are combined within goods whilst manufacturers of goods are stretching their value chains to profit from the provision of services. It has become difficult to differentiate between goods and services, and in many instances the attempt to apply such a distinction distorts understanding of production processes that are inherently complex. Four processes have been at work that require detailed attention: the shift towards service employment, changes to manufacturing, the blurring of services and manufacturing functions and the rise of hybrid products and production systems, and, finally, alterations in the control systems required to manage complex hybrid production systems.

First, the shift in employment towards services in all developed market economies reflects alterations in consumer behaviour (both business-to-business and business-toconsumer) and in the structure of production systems (Bryson et al., 2004). The growth of service functions also reflects changes in the skill sets required. In some accounts this employment shift is considered to indicate the rise of a service economy in which service functions and outputs become increasingly dominant (Illeris, 1996; OECD, 2000; Bryson et al., 2004; Bryson and Daniels, 2007). Such accounts have a tendency to over-emphasise the importance of the rise of service employment and under-emphasise productivity differentials that exist between manufacturing and services. Manufacturing employment has declined in many national economies but productivity improvements have meant that output has risen (Bryson, 2008a). To complicate matters further, many service jobs directly or indirectly support goods production (MacPherson, 1997; Bryson, 2009a). In some cases, service functions that were previously undertaken inside manufacturing firms have been externalised to specialist service suppliers (Goe, 1991; Beyers and Lindahl, 1996; Bryson et al., 2004: 83-85). This type of restructuring produces a statistical anomaly in which service employment appears to grow at the expense of manufacturing jobs (Bryson, 2009a).

Second, manufacturing has changed, or perhaps our understanding of it has changed during this century. Academics and policy-makers have begun to adopt a more complex definition of manufacturing that has been informed by relatively sophisticated accounts of commodity or value chains (Gereffi, 2001; Gereffi et al., 2005; Bryson, 2008b). In this context, the concept of value chain fragmentation has become an important conceptual tool for understanding the evolving structure and new geographies of production systems. The concept of 'fragmentation' highlights the fact that manufacturing involves more than just fabrication, but also includes service functions that are integral to the production of physical goods. This implies that academics and policy-makers have begun to shift their attention away from a narrow fabrication view of manufacturing to one in which manufacturing includes research and development, design functions, marketing and advertising, services that support production processes and a set of services that have been created to support customers' experiences of a product. Manufactured goods should now be conceptualised as products that contain different quantities of service inputs; some of these service inputs are wrapped into a good during the production 
process and some are wrapped around a completed product (Daniels and Bryson, 2002; Livesey, 2006; Department for Business, Enterprise and Regulatory Reform, 2008).

Third, the blurring that has occurred and continues to occur between goods and services implies that these terms are beginning to distort the ways in which academics and policy-makers conceptualise production systems (Howells, 2000; Daniels and Bryson, 2002). This has important implications for academic theory but also impacts on the ways in which national statistical agencies classify economic activity. It also means that regional policy can no longer be targeted at services or manufacturing sectors, but must become increasingly holistic and be designed to enhance the competitiveness of complex production systems consisting of hybridised manufacturing and service processes and ultimately hybrid production systems that produce hybrid products (Bryson, 2008a, b; Bryson et al., 2008b). A hybrid product contains a complex combination of services and manufactured inputs, with both sets of inputs required for the product to function. All production systems are hybrid systems but not all hybrid production systems produce hybrid products.

There is an interesting literature that argues that manufacturing is undergoing a process of 'servitisation' (Neely, 2007). But the term 'servitisation' suggests that services are just being applied to manufacturing as an additional element. This overlooks the ways in which the application of services to manufacturing is more than a process of application but one of transformation. With this in mind, our argument is that a blend of manufacturing and services has led to a process of hybridisation that has led to the development of hybrid production systems and hybrid products. The use of the term 'servitisation' reflects the application of an old language to a new process.

Fourth, the development of hybrid production systems has important implications for the science of management cybernetics that have yet to be explored to any great extent. Simple price-based competition has been replaced or supplemented with other forms of competition founded upon the exploitation of new forms of expertise supported by new control systems (Bryson et al., 2008b). The implication is that management systems must be designed to capture profits that come from services that are woven into and wrapped around products. This means that profit not only occurs at the point of sale of some goods, but also continues as part of a revenue stream that comes from the provision of a range of related services (Giarini, 2002). Management and control within hybrid production systems is a new area that will require considerable further research.

These four processes have important implications for the ways in which firms position their products and services in the marketplace and also for regional and national economic policy. Further detailed research, however, is required in order to explore many of the management and policy implications that come from a shift away from the production of goods towards the creation of hybrid products.

The transformation that is ongoing within manufacturing has its origins in the 19th century (Bryson, 2009b). The provision of services was an important element for many manufacturing firms during the Industrial Revolution. The difference between now and then is the extent and complexity of services that have been incorporated into manufacturing production systems and into physical goods. In 1993, Sandra Vandermerwe was one of the first academics to identify the ways in which firms in all sectors can create added value through the provision of services. The title of her book - From Tin Soldiers to Russian Dolls: Creating Added Value Through Services - highlights the extent of this 
transformation. According to Vandermerwe, 'by the 1990s, for one reason or another, most manufacturing and service firms had concluded that products without services, or services without products, was an untenable position. Both were patently necessary in order to compete. Besides, were products and services so different from each other?' (1993: 47). In this book she poses the question: 'Could a manufacturer really be considered part of the industrial sector anymore if such a large portion of its revenue depended on services?' (Vandermerwe, 1993: 47). This highlights the difficulties of classifying activities using languages and classification systems that reflect the economy as it was structured in the 18th century. It also calls for a new language to describe and understand the structure of economic activity (Daniels and Bryson, 2002). In 2002 we published a paper calling for the development of a new language for a new economic geography. At that time we had no answer to the difficulty of classifying activities into goods and services, but subsequently a solution to this difficulty has emerged (Bryson, 2009b) - namely, to use the term 'production'; all production is a blend of service and manufacturing tasks (Bryson and Rusten, 2011).

There are important control, management and organisational issues to be considered between BPS functions that can be delivered remotely and those that are still dependent upon social relationships that are constructed around face-to-face encounters. In this context it is important to remember that a production process consists of a set of processes and operations (Bryson, 2008b). A process refers to the collection of activities that combined together produce a product, whilst an operation refers to an activity that is performed at a particular point in a production process (Blackstone et al., 1997: 602). Production systems are increasingly founded upon complex combinations of manufacturing and service knowledge. The production of products and services should be conceptualised as a process that consists of a complex and evolving blending of manufacturing and service processes or, perhaps more correctly, producer service processes. This can be conceptualised as a simple equation in which:

\section{Production $(\mathrm{P})=$ Manufacturing Processes $(\mathrm{M})+$ Service Processes $(\mathrm{S})$}

It is impossible to manufacture without services and services cannot be created or delivered without manufactured products (Bryson et al., 2008a). It is therefore important for academics and policy-makers to begin to identify and conceptualise the complex interrelationships that occur between different elements of production processes that together create value. This 'coming together' to create a product (physical product or a service) can take place within the same company or can be part of a coordinated value chain of independent companies that are managed by a company or even an individual. The control of a process should take precedence over operations and all operations must be subordinate to the requirements of the process. Operations may be geographically distributed, since a production process may be designed around the benefits that can accrue from an international division of labour. The production process must be controlled so that the constraints or limitations on the process can be identified and taken into consideration. This also means that individual operations may have to be controlled using different systems to take into consideration the nature of the activity, for example service or product inputs into the overall process, and complexity that is associated with a geographically distributed production system. 


\section{A Case Example: Rolls-Royce and BAE Systems}

Rolls-Royce is one of the most frequently cited examples of a firm that has shifted towards a service-based business model. In the financial year 2006-2007, 55 per cent of its revenues were derived from the delivery of services (Rolls-Royce, 2007: 15). In 1987 Rolls-Royce 'supported our engines in service by offering repair and overhaul arrangements which often failed to align our interests with those of our customers' (Rolls-Royce: 2007: 14). At this time, services were considered as a supporting set of functions rather than as an integral element within the firm's business model. Since 1987, Rolls-Royce has transformed itself into a provider of power rather than a provider of engines. This transformation has occurred in all the firm's core market segments, ranging from civil aviation to defence aerospace and marine engines. The transformation has involved the company in developing:

comprehensive through-life service arrangements in each of our business sectors. These align our interests with those of our customers and enable us to add value through the application of our skills and knowledge of the product. In 2007, underlying aftermarket service revenues grew by nine per cent and represented 55 per cent of Group sales. This growth has been achieved partly as a result of the introduction of new products, but also because our ownership of intellectual property enables us to turn data into information that adds value to our customer. (Rolls-Royce, 2007: 14)

A good example of this shift is the mission ready management solutions (MRMS ${ }^{\circledR}$ ) package supplied by Rolls-Royce. MRMS provides the military with customised solutions that include total support packages and 'Power by the Hour' ${ }^{\circledR}$. With the latter package, major airline and defence customers pay a fixed warranty and operation fee for the hours that an engine runs. Contract performance is measured against the performance of the fleet and in terms of ready for issue engine availability.

Rolls-Royce offers three types of service solutions. First, TotalCare is based upon an agreed rate per engine flying hour and this enables customers to engage in accurate financial forecasting. This package is designed for airline fleets and it transfers the technical and financial aspects of fleet maintenance from the customer to the service supplier. At the same time it converts Rolls-Royce into a service provider or, more precisely, a provider of hybrid products. Second, CorporateCare is intended for corporate and business jet customers and is designed to ensure that the aircraft is available when required; it may also result in increased residual value. Third, MRMS is targeted at defence customers and provides them with engine management and maintenance to ensure operational capability 24 hours per day and seven days per week. These types of hybrid products have transformed Rolls-Royce from a company that designs and manufactures engines to a provider of turnkey engine power (Table 1.2). To maximise profitability, RollsRoyce must now focus on the effective management of an extended manufacturing value chain or its hybrid production system. This includes the design and development of engines, installation, after-sales maintenance, repair and overall services, and parts availability and management.

Many other manufacturing companies sell products that include services. Another excellent example is BAE Systems, the British manufacturer of defence equipment. Currently, BAE is trying to diversify from an over-dependence on defence-related 
Table 1.2 The transformation of Rolls-Royce from a provider of a good to a provider of hybrid products

\begin{tabular}{|c|c|c|c|c|}
\hline $\begin{array}{l}\text { Good } \\
\text { delivery of engine }\end{array}$ & & & $\rightarrow$ & $\begin{array}{l}\text { Service } \\
\text { delivery of power }\end{array}$ \\
\hline $\begin{array}{l}\text { Traditional } \\
\text { Support }\end{array}$ & $\begin{array}{l}\text { Enhanced } \\
\text { Support }\end{array}$ & $\begin{array}{l}\text { Advanced } \\
\text { Support }\end{array}$ & $\begin{array}{l}\text { Total } \\
\text { Support }\end{array}$ & $\begin{array}{l}\text { Extended } \\
\text { support }\end{array}$ \\
\hline $\begin{array}{l}\text { Spare parts } \\
\text { Repair Overhaul }\end{array}$ & $\begin{array}{l}\text { Data forecasting } \\
\text { services } \\
\text { Technical logistics } \\
\text { support } \\
\text { Customer training }\end{array}$ & $\begin{array}{l}\text { Comprehensive } \\
\text { package } \\
\text { integrating } \\
\text { elements of } \\
\text { basic and } \\
\text { enhanced } \\
\text { support } \\
\text { Spares inclusive } \\
\text { Repair Overall } \\
\text { contracts }\end{array}$ & $\begin{array}{l}\text { Complete, } \\
\text { availability- } \\
\text { based services } \\
\text { Can cover all of } \\
\text { an aircraft, or } \\
\text { some element's } \\
\text { of an aircraft's } \\
\text { activity } \\
\text { Configuration } \\
\text { management } \\
\text { and reliability } \\
\text { enhancements } \\
\text { covered }\end{array}$ & $\begin{array}{l}\text { Partnered } \\
\quad \text { capability } \\
\text { Turnkey service } \\
\text { Non-propulsion- } \\
\text { related } \\
\text { support } \\
\text { solutions }\end{array}$ \\
\hline $\begin{array}{l}\text { Customer } \\
\text { responsibility }\end{array}$ & & & $\rightarrow$ & $\begin{array}{l}\text { Service provider } \\
\text { responsibility }\end{array}$ \\
\hline
\end{tabular}

Source: After Rolls-Royce, 2006.

products to commercial products that include engine controls, flight controls and cabin management systems. The company is heavily involved in the development of the F-35 Joint Strike Fighter. This new fighter has cost an estimated \$1 trillion to develop (Clancy, 2014: B5). Lockheed Martin is developing the F-35 for the US government, but $\mathrm{BAE}$ is the largest partner and is responsible for producing 15 per cent of the aircraft. BAE is making parts for the fuselage and tail for every F-35 at its Samlesbury factory located in the north-west of England and the components are shipped to the final assembly line in Fort Worth, Texas. This British element accounts for 10 per cent of the plane, with another 5 per cent manufactured by BAE in the US. The F-35 is anticipated to have a life expectancy of 50 years. For BAE the F-35 programme offers two opportunities to generate profit - first, through the design and manufacture of components and, second, via the provision of a constant stream of services for all the planes. The manufacturing element represents a single moment to create value or profit, but the service element will provide BAE with service-generated profits for up to 50 years.

Both these examples of hybrid products are from heavy engineering, but the hybridisation between manufacturing and services is occurring across all manufacturing sectors. 


\section{CONCLUSIONS}

The development of hybrid production systems and hybrid products represents a radical alteration to the ways in which products are produced and consumed. At one level, this represents a breakdown of the long-standing and simple bi-polar distinction that is made between services and manufacturing. Increasingly, this division is no longer helpful as manufactured products acquire many of the characteristics of services. This has three important implications that need to be considered.

First, economic theory needs to be refined to take into consideration the demise of the manufacturing/service divide. This has important implications for the ways in which the creation of profit is theorised. Profit should not be conceptualised as something that is created by a single transaction involving the transfer of the ownership of a product from a producer to a consumer. Instead, profit occurs through multiple moments of exchange. The physical good may have limited value whilst profit is created and acquired through the sale of embedded services, spare parts or consumables.

Second, the way in which governments collect statistical data about the economy will have to be revised. Too many service functions are hidden within manufacturing firms and many manufacturing firms are really providers of hybrid products. The longestablished Standard Industrial Classification (SIC) codes may have to move towards a system in which firms are categorised on the basis of an analysis of jobs, functions and tasks (rather than just their principal product). Alternatively, new SIC codes could be developed to identify firms in particular sectors that have developed hybrid production systems and products.

Third, economic policy will have to alter to take into consideration the shift towards hybrid production systems. This means that policies must embrace complete value chains rather than being targeted at manufacturing or service elements. Manufacturing firms should be encouraged to develop service expertise and explore ways in which services can add value to their existing business models. Services and their hybridisation with manufacturing processes provide an important source of inimitability. This process of hybridisation requires further detailed study.

The shift in emphasis towards hybrid production systems is also a shift towards a production system that might be more resilient during periods of economic downturn or recession. A firm that only sells goods has great difficulties during an economic downturn unless it sells goods that are essential rather than a discretionary purchase. A firm that sells hybrid products may have difficulties in selling the manufactured product during an economic downturn, but should have developed an extensive network of existing captive 'service' customers. These may have signed service contracts that represent a continual income stream for the provider of a hybrid product or represent opportunities for the sale of new product-supporting services. Further research is required to compare different business models and their ability to create wealth during recessionary periods. We are currently living in extremely uncertain times and perhaps the only certainty is that economic competitiveness rests on the ability of companies to design and manage effective hybrid production systems and to produce hybrid products that blend services and manufacturing elements together in increasingly novel ways. 


\section{BIBLIOGRAPHY}

Barnett, D. (1998), London: Hub of the Industrial Revolution: A Revisionary History: 1775-1825, Tauris Academic Studies: London.

Baumol, W. (1967), 'Macroeconomics of unbalanced growth: the anatomy of an urban crisis', American Economic Review, 57, 415-426.

Baumol, W., Blackman, S. and Wolf, E. (1989), Productivity and American Leadership, MIT Press: Cambridge, MA.

Bell, D. (1973), The Coming of Post-Industrial Society: A Venture in Social Forecasting, Basic Books: New York.

Beyers, W.B. and Alvine, M.J. (1985), 'Export services in post-industrial society', Papers of the Regional Science Association, 57, 33-45.

Beyers, W.B. and Lindahl, D.P. (1996), 'Explaining the demand for producer services', Papers in Regional Science, 75, 351-374.

Blackstone, J.H., Gardiner, L.R. and Gardiner, S.C. (1997), 'A framework for the systemic control of organizations', International Journal of Production Research, 35, 3, 597-609.

Braudel, F. (1988), Civilization and Capitalism 15th-18th Century: The Wheel of Commerce, Collins: London.

Bryson, J.R. (1996), 'Small business service firms and the 1990s recession in the United Kingdom: implications for local economic development', Local Economy Journal, 11, 221-236.

Bryson, J.R. (1997a) 'Business service firms, service space and the management of change', Entrepreneurship and Regional Development, 9, 93-111.

Bryson, J.R. (1997b), 'Small and medium-sized enterprises, Business Link and the new knowledge workers', Policy Studies, 18, 1, 67-80.

Bryson, J.R. (2008a), 'Service economies, spatial divisions of expertise and the second global shift', in P.W. Daniels et al. (eds), Human Geography: Issues for the 21st Century, Prentice Hall: London, third edition, pp. 339-357.

Bryson, J.R. (2008b), 'Value chains or commodity chains as production projects and tasks: towards a simple theory of production', in Dieter Spath and Walter Ganz (eds), The Future of Services: Trends and Perspectives, Carl Hanser Verlag: Munich, pp. 265-284.

Bryson, J.R. (2009a) 'Economic geography: business services', in R. Kitchin and N. Thrift (eds), International Encyclopaedia of Human Geography, Elsevier: Oxford, pp. 368-374.

Bryson, J.R. (2009b) 'Service innovation and manufacturing innovation: bundling and blending services and products in hybrid production systems to produce hybrid products', in F. Gallouj (ed.), Handbook on Innovation in Services, Edward Elgar: Cheltenham and Northampton, MA, pp. 679-700.

Bryson, J.R. (2009c), Hybrid Manufacturing Systems and Hybrid Products: Services, Production and Industrialisation, University of Aachen: Aachen.

Bryson, J.R. and Daniels, P.W. (2007), 'Service worlds', in J.R. Bryson and P.W. Daniels (eds), The Handbook of Service Industries in the Global Economy, Edward Elgar: Cheltenham and Northampton, MA.

Bryson, J.R. and Rusten, G. (2011), Design Economies and the Changing World Economy: Innovation, Production and Competitiveness, Routledge: London.

Bryson, J.R., Daniels, P.W. and Warf, B. (2004), Service Worlds: People, Organisations, Technologies, Routledge: London.

Bryson, J.R., Keeble, D. and Wood, P. (1993a), 'The creation, location and growth of small business service firms in the United Kingdom', Service Industries Journal, 13, 2, 118-131.

Bryson, J.R., Keeble, D. and Wood, P. (1993b), 'Business networks, small firm flexibility and regional development in UK business services', Entrepreneurship and Regional Development, 5, 265-277.

Bryson, J.R., Keeble, D. and Wood, P. (1994), Enterprising Researchers: The Growth of Small Market Research Firms in Britain, Business Services Research Monograph, Series 1, No. 2, Small Business Research Trust.

Bryson, J.R., Keeble, D. and Wood, P. (1997), 'The creation and growth of small business service firms in postindustrial Britain', Small Business Economics, 9, 4, 345-360.

Bryson, J.R., Taylor, M. and Cooper, R. (2008a), 'Competing by design, specialization and customization: manufacturing locks in the West Midlands (UK)', Geografiska Annaler: Series B, Human Geography, 90, 2, 173-186.

Bryson, J.R., Taylor, M. and Daniels, P.W. (2008b), 'Commercializing "creative" expertise: business and professional services and regional economic development in the West Midlands, UK', Politics and Policy, 36, 2, 306-328.

Clancy, R. (2014), 'There's going to be consolidation in defence', Daily Telegraph, Monday July 14, B5.

Daniels, P.W. (ed.) (1979), Spatial Patterns of Office Growth and Location, John Wiley \& Sons: Chichester.

Daniels, P.W. (1982), Service Industries: Growth and Location, Cambridge University Press: Cambridge.

Daniels, P.W. (1985), Service Industries: A Geographical Appraisal, Methuen: London. 


\section{Handbook of service business}

Daniels, P.W. and Bryson, J.R. (2002), 'Manufacturing services and servicing manufacturing: changing forms of production in advanced capitalist economies', Urban Studies, 39, 5-6, 977-991.

Deane, P. (1969), The First Industrial Revolution, Cambridge University Press: Cambridge.

Deane, P. and Cole, W. (1962), British Economic Growth 1688-1959, Cambridge University Press: Cambridge.

Department for Business, Enterprise and Regulatory Reform (2008), Manufacturing: New Challenges, New Opportunities, BERR: London.

Fellowes, E.H. (1954), 'Service', in E. Blow (ed.), Grove's Dictionary of Music and Musicians, Macmillan \& Co. Ltd: London, pp. 719-723.

Fuchs, V.R. (1965), 'The growing importance of the service industries', Journal of Business of the University of Chicago, 38, 360-362.

Fuchs, V.R. (1968), The Service Economy, Columbia University Press: New York.

Fuchs, V.R. (1969), Production and Productivity in the Service Industries, National Bureau of Economic Research: New York.

Galbraith, J.K. (1967), The New Industrial State, Hamish Hamilton: London.

Gallouj, F. and Djellal, F. (eds) (2010), The Handbook of Innovation and Services: A Multi-disciplinary Perspective, Edward Elgar: Cheltenham and Northampton, MA.

Gereffi, G. (2001), 'Shifting governance structures in global commodity chains, with special reference to the internet', American Behavioural Scientist, 44, 1616-1637.

Gereffi, G., Humphrey, J. and Sturgeon, T. (2005), 'The governance of global value chains', Review of International Political Economy, 12, 78-104.

Gershuny, J. (1978), After Industrial Society? The Emerging Self-Service Economy, Macmillan: London.

Gershuny, J. and Miles, I. (1983), The New Service Economy: The Transformation of Employment in Industrial Societies, Pinter Publishers: London.

Giarini, O. (2002), 'The globalization of services in economic theory and economic practice: some conceptual issues', in J.R. Cuadrado, L. Rubalcaba and J.R. Bryson (eds), Trading Services in the Global Economy, Edward Elgar: Cheltenham and Northampton, MA, pp. 58-77.

Goddard, J.B. (1986), 'Advanced telecommunications and regional economic development', The Geographical Journal, 152, 383-397.

Goe, R. (1991), 'The growth of producer services industries: sorting through the externalization debate', Growth and Change, 22, 118-141.

Gowers, E. (1982), The Complete Plan Words, Penguin: Harmondsworth.

Gray, A.B. (1921), Cambridge Revisited, W. Heffer \& Sons: Cambridge.

Greenfield, H.I. (1966), Manpower and the Growth of Producer Services, Columbia University Press: New York.

Howells, J. (2000). The Nature of Innovation in Services, report presented to the OECD Innovation and Productivity Workshop, Sydney, Australia, October.

Hyde, F.E. (1973), Far Eastern Trade: 1860-1914, Adam \& Charles Black: London.

Illeris, S. (1996), The Service Economy: A Geographical Approach, Wiley: Chichester.

Lash, S. and Urry, J. (1994), Economies of Signs and Spaces, Sage: London.

Lewis, R. and Maude, A. (1952), Professional People, Phoenix House: London.

Livesey, F. (2006), Defining High Value Manufacturing, Institute for Manufacturing: Cambridge.

MacPherson, A. (1997), 'The role of producer services outsourcing in the innovation performance of New York state manufacturing firms', Annals of the Association of American Geographers, 87, 1, 52-71.

Maglio, P.P., Kieliszewski, C.A. and Spohrer, J.C. (eds) (2010), Handbook of Service Science, Springer: New York.

Marsh, D.C. (1977), The Changing Structure of England and Wales: 1871-1961, Routledge \& Kegan Paul: London.

Moretti, E. (2013), The New Geography of Jobs, Mariner Books: Boston, MA.

Neely, A. (2007), The Servitization of Manufacturing: An Analysis of Global Trends, paper presented at the 14th European Operations Management Association Conference, Ankara, Turkey, June.

OECD (2000), The Service Economy, Business and Industry Policy Forum, OECD: Paris.

OECD (2014), Short Term Labour Market Statistics, available at http://stats.oecd.org/index.aspx?queryid= 38899\#, accessed 25 July 2014.

Ogilvy, D. (1983), Ogilvy on Advertising, Pan: London.

Oxford English Dictionary (1991), The Shorter Oxford English Dictionary, Clarendon Press: Oxford.

Pinches, S. (2009), Ledbury: A Market Town and its Tudor Heritage, Phillimore: Chichester.

Riddle, D.I. (1986), Service-Led Growth: The Role of the Service Sector in World Development, Praeger: New York.

Rolls-Royce (2006), MRMS® Mission Ready Management Solutions, Rolls-Royce: London.

Rolls-Royce (2007), Annual Report 2007: A Global Business, Rolls-Royce: London.

Sayer, A. and Walker, R. (1992), The New Social Economy: Reworking the Division of Labour, Blackwell: Oxford. 
Smith, A. (1977 [1776]), The Wealth of Nations, Penguin Books: Harmondsworth.

Twitchell, J.B. (2004), Branded Nation: The Marketing of Megachurch, College Inc., and Museumworld, Simon \& Schuster: New York.

Urry, J. (1987), 'Some social and spatial impacts of services', Environment and Planning D: Society and Space, $5,5-26$.

Urry, J. (1990), 'Work, production and social relations', Work, Employment and Society, 4, 271-280.

Vandermerwe, S. (1993), From Tin Soldiers to Russian Dolls: Creating Added Value Through Services, Butterworth-Heinemann: Oxford.

Walker, R. (1985), 'Is there a service economy? The changing capitalist division of labour', Science and Society, 49, 1, 42-83.

White, A. (2013), 'Land Secs goes shopping at Bluewater in £656m deal', The Daily Telegraph, 26 June, B5.

Wright Mills, C. (1953), White Collar Work: The American Middle Classes, Oxford University Press: New York. 
John R. Bryson and Peter W. Daniels - 9781781000410 